\title{
Effect of physical damage to ears of corn before harvest and treatment with various additives on the concentration of mycotoxins, silage fermentation, and aerobic stability of corn silage
}

\author{
R. S. Teller, ${ }^{\star}$ R. J. Schmidt, ${ }^{*}$ L. W. Whitlow,† and L. Kung Jr. ${ }^{\star 1}$ \\ *Department of Animal and Food Sciences, University of Delaware, Newark 19716 \\ †Department of Animal Science, North Carolina State University, Raleigh 27695
}

\begin{abstract}
We studied the effects of damaging ears of corn in the field prior to harvest and the use of various additives on the production of selected mycotoxins, silage fermentation, and aerobic stability of whole plant corn. In experiment 1, ears of corn were undamaged or were slashed with a knife $7 \mathrm{~d}$ before harvesting, exposing damaged kernels to the environment. Corn plants were harvested (about 35\% DM) and treated in a $2 \times 2$ factorial arrangement of treatments. Treatments were undamaged or damaged plants, untreated or treated with Lactobacillus buchneri 40788 (400,000 cfu/g of fresh forage) and Pediococcus pentosaceus (100,000 cfu/g). Damaging ears prior to harvest increased the amount of fumonisin but decreased the amount of starch in harvested corn plants. After ensiling, corn silage made from plants damaged before harvest had lower starch but greater concentrations of deoxynivalenol and fumonisin than silage made from plants that were undamaged. Microbial inoculation resulted in fewer yeasts and lower concentrations of zearalenone in silage when compared to uninoculated silage. Inoculated silage also had more acetic acid and 1,2-propanediol than did uninoculated silage. In experiment 2 , ears of corn were undamaged or were slashed with a knife $27 \mathrm{~d}$ or $9 \mathrm{~d}$ before harvesting for corn silage. Whole plants were harvested at about $36 \% \mathrm{DM}$ in a $2 \times 3$ factorial arrangement of treatments. Factors were time of damaging the ears $(27 \mathrm{~d}, 9 \mathrm{~d}$, or no damage) relative to harvest and no additive or $0.1 \%$ (fresh weight) potassium sorbate. Damaging plants 9 $\mathrm{d}$ prior to harvest did not affect the concentrations of deoxynivalenol, fumonisin, and zearalenone in plants at harvest. However, concentrations of deoxynivalenol and fumonisin were increased in fresh forage that had ears damaged at $27 \mathrm{~d}$ when compared to corn plants that were undamaged. Corn plants damaged for $27 \mathrm{~d}$ prior to harvest also had a lower concentration of starch than
\end{abstract}

Received June 8, 2011.

Accepted October 21, 2011

${ }^{1}$ Corresponding author: lksilage@udel.edu corn damaged for $9 \mathrm{~d}$ but was higher in acid detergent fiber than other treatments. The addition of potassium sorbate at harvest had no effect on the concentrations of mycotoxins in the resulting silage, but concentrations of mycotoxins were still greatest in silage made from plants that were damaged the longest prior to harvest $(27 \mathrm{~d})$. Silages treated with potassium sorbate had fewer yeasts and molds than silages without the additive. Damaging ears of corn before harvest had no effects on the aerobic stability of silages in both experiments. In contrast, the addition of the inoculant and potassium sorbate improved aerobic stabilities of silages when compared to untreated silages. These studies showed that physical damage to ears of corn prior to harvest can result in the production of mycotoxins in the field. This finding suggests that producers should test corn silage for mycotoxins prior to feeding especially if the forage has been subjected to physical damage prior to ensiling.

Key words: silage, mycotoxin, potassium sorbate, Lactobacillus buchneri

\section{INTRODUCTION}

A variety of mycotoxins produced from fungi can be found in silages that are fed to dairy cattle (Driehuis et al., 2008). Their presence is undesirable because they have the potential to induce negative effects on the health of animals (CAST, 2003; Adesogan, 2006). Mycotoxins can accumulate on the plant in the field before harvest (Doerr, 2010), during storage, or during processing or feeding (Whitlow and Hagler, 2008). Queiroz et al. (2009) reported that use of a microbial inoculant prevented the accumulation of aflatoxin in rust-infected corn silage during ensiling. Thus, use of an antifungal preservative could potentially prevent the growth of molds during ensiling and storage and may limit the production of mycotoxins formed during this time.

Munkvold (2003) noted that the presence of mycotoxins on corn was dependent on susceptibility of the plant, environmental conditions that encouraged infec- 
tions, and the presence of fungi capable of producing toxins. A common avenue of fungal infection occurs from damage to plants by insects (Dowd, 1998). This results in easy access to nutrients for fungal spores and encourages colonization because fungal hyphae are able to penetrate into the plant (Jouany, 2007). The thick waxy layer of the corn kernel pericarp is an important factor in limiting the accumulation of mycotoxins on kernels of corn. Sampietro et al. (2009) reported that the removal of kernel wax with chloroform increased the concentration of fumonisin (FB1) on corn kernels. Specifically, high concentrations of mycotoxins are often associated with damage to kernels. Ono et al. (2006) reported FB1 levels between 11.5 to 166 -fold greater in damaged versus healthy kernels of corn.

Our hypothesis was that damaging ears of corn prior to harvest would increase the probability of harvesting corn for silage with more undesirable microorganisms or more mycotoxins, or both. We also hypothesized that using various additives might decrease the potential for mycotoxin production in the silo and improve aerobic stability of the resulting silage. Thus, the objective of this study was to evaluate the effect of damaging ears of corn prior to harvest and ensiling with and without various additives on the concentrations of mycotoxins, silage fermentation, nutritive value, and aerobic stability of corn silage.

\section{MATERIALS AND METHODS}

\section{Experiment 1}

Pioneer 3334B62 (Pioneer Hi-Bred International Inc., Johnston, IA) was planted at the University of Delaware Dairy Farm for use by the herd. When the corn kernels were in the early milk stage of maturity, 4 random rows had the ears of the plants in those rows slashed lengthwise with a knife in two different locations $180^{\circ}$ apart. Seven days later, undamaged (from rows adjacent to the damaged rows) and damaged plants were harvested manually and fed through a self-propelled forage harvester (New Holland FP230; New Holland Agriculture, New Holland, PA). Approximately 20 undamaged plants from another section of the field were fed through the chopper to clean the system. Undamaged plants for the study were then chopped separately for each of the 4 rows, followed by each row for the damaged plants. Chopped forages from each individual row for damaged and undamaged corn plants were made into separate $75-\mathrm{kg}$ piles for each of the following treatments and included 1) undamaged plants treated with nothing; 2) undamaged plants treated with Lactobacillus buchneri $40788\left(4 \times 10^{5} \mathrm{cfu} / \mathrm{g}\right)$ and Pediococcus pentosaceus $(1$ $\times 10^{5} \mathrm{cfu} / \mathrm{g}$; Lallemand Animal Nutrition, Milwaukee,
WI); 3) damaged plants treated with nothing; or 4) damaged plants treated with L. buchneri and P. pentosaceus. The microbial inoculant was applied via 250 $\mathrm{mL}$ of water that was sprayed onto the fresh forage under constant mixing. Forage piles without inoculation (INOC) received a similar amount of water. Samples of each pile were collected immediately and placed on ice until further analysis. Forage from each treatment was packed in quadruplicate 20-L bucket silos to obtain a final packing density of approximately $239 \mathrm{~kg}$ of DM/ $\mathrm{m}^{3}$. Silos were covered with a double layer of black plastic (2 mil), sealed with duct tape, and allowed to ensile for $126 \mathrm{~d}$ in a closed barn $\left(20-25^{\circ} \mathrm{C}\right)$.

Water extracts of fresh forage and silages were prepared by homogenizing $25 \mathrm{~g}$ of plant material and 225 $\mathrm{mL}$ of one-fourth strength Ringer's solution (Oxoid BR52; Oxoid, Unipath Ltd., Basingstoke, UK) for 1 min on a medium setting in a Proctor Silex 57171 blender (Hamilton Beach/Proctor-Silex Inc., Washington, $\mathrm{NC}$ ). The $\mathrm{pH}$ was measured and a portion of the water extract was filtered through Whatman 54 filter paper (Whatman Inc., Clifton, NJ), acidified with $50 \% \mathrm{H}_{2} \mathrm{SO}_{4}$, and frozen before chemical analyses. The water extracts were analyzed for ammonia- $\mathrm{N}$ using a phenol-hypochlorite method (Weatherburn, 1967). The water-soluble carbohydrate (WSC) content of forages and silages was determined using a colorimetric method described by Nelson (1944). A portion of the fresh water extracts was filtered though a double layer of cheesecloth and enumerated for yeasts and molds by pour plating in malt extract agar (Oxoid CM59; Oxoid, Unipath Ltd.) that had been acidified with $85 \%$ lactic acid at a rate of $0.5 \%(\mathrm{vol} / \mathrm{vol})$. Plates were incubated aerobically in a $32^{\circ} \mathrm{C}$ oven for $2 \mathrm{~d}$ before counting. Water extracts for silages were also analyzed for short-chain organic acids, 1,2-propanediol, and ethanol by HPLC, as described by Muck and Dickerson (1988).

On the day of silo opening, laboratory silos were weighed and DM recovery was calculated based on the initial weight of forage DM placed in the silos and the amount of silage DM remaining after ensiling. Upon silo opening, silage from each silo was placed in clean 20-L silos and exposed to air $\left(25^{\circ} \mathrm{C}\right)$. Each silo was covered with a double-layer of sterile cheesecloth to prevent contamination and drying out of the forage mass, yet allowing air to infiltrate the mass. A thermocouple wire was placed in the geometric center of the forage mass in 1 of the 2 buckets. The wire was attached to a data logger (model number CR10X; Campbell Scientific Inc., Logan, UT), which recorded the temperature every $10 \mathrm{~min}$ and averaged these values every $2 \mathrm{~h}$. Aerobic stability was defined as the number of hours that silage was exposed to air before a $2^{\circ} \mathrm{C}$ increase in temperature above baseline temperature was observed. 
The DM content of forages and silages was determined by placing representative samples in a forced-air oven at $60^{\circ} \mathrm{C}$ for $48 \mathrm{~h}$. Dried forage and silage samples were ground with a UDY Cyclone Sample Mill (UDY Corp., Fort Collins, CO) with a 1-mm screen. Samples were analyzed for NDF using sulfite and amylase (Van Soest et. al., 1991) and ADF (Robertson and Van Soest, 1981) using an Ankom ${ }^{200}$ Fiber Analyzer (Ankom Technology, Fairport, NY). Crude protein content was determined by total combustion of the sample (LECO CNS 2000 Analyzer; LECO Corp., St. Joseph, MI) and multiplying total $\mathrm{N}$ by 6.25 . Starch content was determined by the method described by Hall (2000). Mycotoxins were analyzed on dried samples. Deoxynivalenol (DON) was quantified using capillary gas chromatography (Tacke and Casper, 1996), using a Romer MycoSep \#227 column (Romer Labs Inc., Union, MO) for sample clean up. Fumonisin (Bennett and Richard, 1994) and zearalenone (ZEA) were analyzed via HPLC (Romer Labs Inc., 2000).

\section{Experiment 2}

Pioneer 33B51 (Pioneer Hi-Bred International Inc.) corn hybrid was used in this experiment. Four random rows of corn plants had their ears slashed lengthwise in two different locations $180^{\circ}$ apart (27 d before harvest). When the kernels reached dent stage, another set of 4 rows had the ears of the plants damaged as previously described ( $9 \mathrm{~d}$ before harvest). When corn plants reached about 36\% DM, plants from undamaged adjacent rows and damaged rows were harvested manually as described in experiment 1. Treatments included 1) nothing, undamaged plants; 2) potassium sorbate (PS) added at $0.1 \%$ fresh forage weight, undamaged plants; 3) nothing, plants damaged $9 \mathrm{~d}$ before harvest; 4) PS, plants damaged $9 \mathrm{~d}$ before harvest; 5) nothing, plants damaged $27 \mathrm{~d}$ before harvest; or 6) PS, plants damaged $27 \mathrm{~d}$ before harvest. Potassium sorbate was applied via $250 \mathrm{~mL}$ of water that was sprayed onto the fresh forage under constant mixing. Forages without addition of PS received just water. Silos, management, and analyses were as described for experiment 1, with the exception that silos were stored for $95 \mathrm{~d}$ prior to opening.

\section{Statistical Analysis}

All microbial data were transformed to $\log _{10}$ and are presented on a wet weight basis, whereas chemical data ( $\mathrm{pH}$ and $\mathrm{DM}$ content) are presented on a DM basis. Data for mycotoxins were also transformed to $\log _{10}$ and are presented on a DM basis. Data for freshly chopped forage were analyzed as a randomized complete block design using the MIXED procedure of SAS (Version
9.1; SAS Institute, 2004). For experiment 1, data were analyzed using a mixed model for a $2 \times 2$ factorial arrangement of treatments with main effects for INOC, damage $(\mathbf{D})$, and the interaction between INOC $\times$ D. Data from experiment 2 were analyzed using the MIXED procedure SAS for a $2 \times 3$ factorial with 2 amounts of PS (untreated or treated) and 3 levels of D (undamaged, damaged for $9 \mathrm{~d}$, or damaged for 27 d). The model included effects for PS, D, and PS $\times$ D. Silo was the random variable in each experiment. Treatment means were compared using the Tukey test (Snedecor and Cochran, 1980) when $P \leq 0.05$.

\section{RESULTS}

\section{Experiment 1}

The chemical and microbiological compositions of fresh forage immediately after harvest are shown in Table 1. Of the nutritional components, only the concentration of starch was lower in damaged versus undamaged corn plants. The numbers of yeasts and molds were similar between treatments. Damage to ears of corn prior to harvest resulted in plants with higher concentrations of FB1 $(5.80 \mathrm{mg} / \mathrm{kg})$ when compared to undamaged plants $(0.10 \mathrm{mg} / \mathrm{kg})$. However, the concentrations of DON and ZEA were unaffected by plant damage.

The DM recovery from silos and composition of silages are shown in Table 2. The DM recovery of silage was greatest in silages that had been damaged but uninoculated compared to other treatments. Inoculated silages were lower in DM content but the differences were very small. Damaged and inoculated corn silage had higher $\mathrm{CP}$ content than other treatments. Damaged corn was higher in $\mathrm{NH}_{3}-\mathrm{N}$ than was undamaged corn and the effect was bigger when the silage had been inoculated. Inoculation and damage to the plant did not affect the ADF and NDF content or the number of molds in silage. However, silage from plants that had been damaged was, on average, $16.1 \%$ lower in starch content than in silage from undamaged plants. Overall, INOC resulted in fewer numbers of yeasts when compared to uninoculated silage. Concentrations of DON and FB1 were unaffected by INOC but were higher in silages from damaged plants. In contrast, INOC resulted in silage with lower concentrations of ZEA but this was only the case in silage from undamaged plants and the effect was small. The fermentation characteristics of silages are shown in Table 3. Differences were observed among the $\mathrm{pH}$ of the treatments but they were small, as the range in $\mathrm{pH}$ was from 3.57 to 3.62. Microbial INOC resulted in silages with higher concentrations of lactic acid, acetic acid, and 1,2-propanediol but did not affect 
Table 1. The DM, pH, chemical composition (DM basis), mycotoxins (DM basis), and microbial populations (fresh weight basis) of chopped whole plant corn plants at harvest before treatment with an inoculant in experiment 1

\begin{tabular}{|c|c|c|c|c|}
\hline Item & $\begin{array}{l}\text { Undamaged } \\
\text { plants }\end{array}$ & $\begin{array}{l}\text { Damaged } \\
\text { plants }^{2}\end{array}$ & SEM & $P$-value \\
\hline DM, \% & 36.39 & 33.57 & 1.43 & 0.32 \\
\hline $\mathrm{pH}$ & 5.55 & 5.42 & 0.24 & 0.67 \\
\hline $\mathrm{CP}, \%$ & 8.60 & 8.63 & 0.69 & 0.30 \\
\hline $\mathrm{NH}_{3}-\mathrm{N}, \%$ & 0.03 & 0.03 & $<0.01$ & 0.70 \\
\hline $\mathrm{WSC}^{3} \%$ & 8.49 & 10.30 & 0.98 & 0.18 \\
\hline $\mathrm{ADF}, \%$ & 24.81 & 24.04 & 0.57 & 0.39 \\
\hline NDF, $\%$ & 44.06 & 42.28 & 1.24 & 0.43 \\
\hline Starch, \% & $30.90^{\mathrm{a}}$ & $25.82^{\mathrm{b}}$ & 0.53 & 0.05 \\
\hline Yeasts, $\log \mathrm{cfu} / \mathrm{g}$ & 6.65 & 6.72 & 0.40 & 0.68 \\
\hline Molds, log cfu/g & 5.93 & 5.88 & 0.28 & 0.69 \\
\hline Deoxynivalenol, mg/kg & 0.88 & 0.51 & 0.25 & 0.78 \\
\hline Fumonisin $\mathrm{B}_{1}, \mathrm{mg} / \mathrm{kg}$ & $0.10^{\mathrm{b}}$ & $5.80^{\mathrm{a}}$ & 0.62 & 0.05 \\
\hline Zearalenone, $\mathrm{mg} / \mathrm{kg}$ & 0.12 & 0.15 & 0.03 & 0.46 \\
\hline
\end{tabular}

a,b Means within rows with unlike superscripts differ $(P<0.05)$.

${ }^{1}$ Plants were undamaged prior to harvest.

${ }^{2}$ Plants were damaged $7 \mathrm{~d}$ prior to harvest.

${ }^{3}$ Water-soluble carbohydrates.

the concentration of ethanol in silage. Damaging plants prior to harvest had no effect on fermentation end products with the exception that there was a trend $(P$ $<0.06$ ) for these silages to have more ethanol (average of $5.40 \%$ ) when compared to silage made from undamaged plants (average $4.32 \%$ ). Damage to the plant did not affect the aerobic stability of the resulting silage but silages that had been inoculated at ensiling were more stable than uninoculated silages.

\section{Experiment 2}

The composition of freshly chopped corn plants is shown in Table 4. Forage DM was different among treatments but these differences were biologically small because the range was from 35.5 to $37.6 \%$. The concentrations of $\mathrm{CP}, \mathrm{NDF}$, and $\mathrm{NH}_{3}-\mathrm{N}$, and $\mathrm{pH}$ were unaffected by damage to the ear but ADF was greater in plants damaged for $27 \mathrm{~d}$ than undamaged plants

Table 2. The composition of corn silage after $126 \mathrm{~d}$ of ensiling from experiment $1^{1}$

\begin{tabular}{|c|c|c|c|c|c|c|c|c|}
\hline \multirow[b]{2}{*}{ Composition } & \multirow[b]{2}{*}{$\begin{array}{c}\text { Undamaged } \\
\text { control }^{2}\end{array}$} & \multirow[b]{2}{*}{$\begin{array}{c}\text { Undamaged } \\
\text { INOC }^{3}\end{array}$} & \multirow[b]{2}{*}{$\begin{array}{c}\text { Damaged } \\
\text { control }\end{array}$} & \multirow[b]{2}{*}{$\begin{array}{c}\text { Damaged } \\
\text { INOC }\end{array}$} & \multirow[b]{2}{*}{ SEM } & \multicolumn{3}{|c|}{$P$-value } \\
\hline & & & & & & $\mathrm{IN}^{4}$ & $\mathrm{D}^{5}$ & $\mathrm{IN} \times \mathrm{D}$ \\
\hline $\mathrm{DMR}^{6} \%$ & $88.6^{\mathrm{b}}$ & $86.8^{\mathrm{b}}$ & $96.4^{\mathrm{a}}$ & $89.1^{\mathrm{b}}$ & 1.1 & $<0.01$ & $<0.01$ & 0.04 \\
\hline DM, \% & $32.7^{\mathrm{a}}$ & $32.1^{\mathrm{ab}}$ & $32.9^{\mathrm{a}}$ & $31.2^{\mathrm{b}}$ & 0.3 & $<0.01$ & 0.35 & 0.08 \\
\hline $\mathrm{CP}, \%$ & $7.60^{\mathrm{b}}$ & $7.60^{\mathrm{b}}$ & $7.40^{\mathrm{b}}$ & $8.20^{\mathrm{a}}$ & 0.15 & 0.20 & 0.02 & 0.02 \\
\hline $\mathrm{NH}_{3}-\mathrm{N}, \%$ & $0.06^{\mathrm{c}}$ & $0.06^{\mathrm{c}}$ & $0.07^{\mathrm{b}}$ & $0.08^{\mathrm{a}}$ & $<0.01$ & $<0.01$ & $<0.01$ & $<0.01$ \\
\hline WSC, ${ }^{7} \%$ & $1.00^{\mathrm{c}}$ & $0.50^{\mathrm{d}}$ & $1.25^{\mathrm{a}}$ & $1.13^{\mathrm{b}}$ & 0.04 & $<0.01$ & $<0.01$ & $<0.01$ \\
\hline $\mathrm{ADF}, \%$ & 27.3 & 25.3 & 26.8 & 26.8 & 1.3 & 0.47 & 0.68 & 0.47 \\
\hline $\mathrm{NDF}, \%$ & 45.2 & 42.8 & 45.0 & 45.4 & 1.8 & 0.59 & 0.51 & 0.46 \\
\hline Starch, \% & $26.2^{\mathrm{ab}}$ & $30.8^{\mathrm{a}}$ & $24.4^{\mathrm{ab}}$ & $23.4^{\mathrm{b}}$ & 2.1 & 0.42 & 0.05 & 0.22 \\
\hline Yeasts, ${ }^{8} \log \mathrm{cfu} / \mathrm{g}$ & $3.78^{\mathrm{a}}$ & $0^{\mathrm{c}}$ & $2.9^{\mathrm{ab}}$ & $1.21^{\mathrm{bc}}$ & 0.8 & $<0.01$ & 0.84 & 0.22 \\
\hline Molds, ${ }^{8} \log \mathrm{cfu} / \mathrm{g}$ & 2.02 & 0.94 & 0.97 & 0.99 & 0.91 & 0.57 & 0.59 & 0.55 \\
\hline Deoxynivalenol, $\mathrm{mg} / \mathrm{kg}$ & $0.92^{\mathrm{c}}$ & $1.09^{\mathrm{c}}$ & $3.12^{\mathrm{b}}$ & $4.62^{\mathrm{a}}$ & 0.40 & 0.06 & $<0.01$ & 0.12 \\
\hline Fumonisin $\mathrm{B}_{1}, \mathrm{mg} / \mathrm{kg}$ & $4.00^{\mathrm{b}}$ & $4.15^{\mathrm{b}}$ & $8.50^{\mathrm{a}}$ & $9.60^{\mathrm{a}}$ & 1.12 & 0.58 & $<0.01$ & 0.67 \\
\hline Zearalenone, $\mathrm{mg} / \mathrm{kg}$ & $1.03^{\mathrm{a}}$ & $0.24^{\mathrm{b}}$ & $0.46^{\mathrm{b}}$ & $0.26^{\mathrm{b}}$ & 0.11 & 0.02 & 0.02 & $<0.01$ \\
\hline
\end{tabular}

\footnotetext{
${ }^{\mathrm{a}-\mathrm{c}}$ Means in rows with unlike superscript letters differ significantly $(P<0.05)$.

${ }^{1}$ Undamaged plants were undamaged prior to harvest and damaged plants were damaged $7 \mathrm{~d}$ prior to harvest.

${ }^{2}$ Control $=$ no inoculant.

${ }^{3} \mathrm{INOC}=$ treated with a microbial inoculant.

${ }^{4}$ Effect of microbial inoculation.

${ }^{5}$ Effect of damage to the plant.

${ }^{6}$ Dry matter recovery.

${ }^{7}$ Water-soluble carbohydrates.

${ }^{8}$ Fresh weight basis.
} 
Table 3. Fermentation end products and aerobic stability of corn silage after $126 \mathrm{~d}$ of ensiling in experiment $1^{1}$

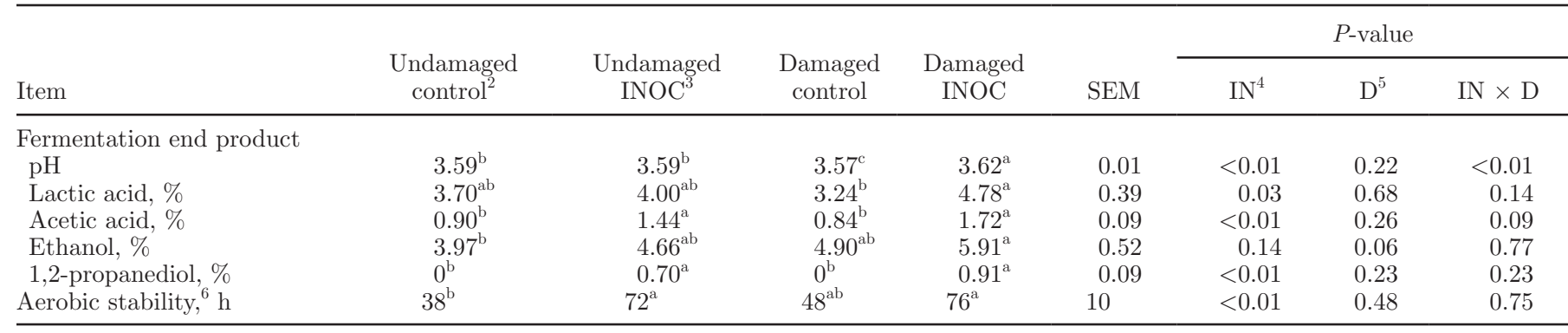

${ }^{\mathrm{a}-\mathrm{c}}$ Means in rows with unlike superscript letters differ significantly $(P<0.05)$.

${ }^{1}$ Undamaged plants had no damage prior to harvest and damaged plants had physical damage to ears $7 \mathrm{~d}$ prior to harvest.

${ }^{2}$ Control $=$ no inoculant.

${ }^{3} \mathrm{INOC}=$ treated with a microbial inoculant.

${ }^{4}$ Effect of microbial inoculation.

${ }^{5}$ Effect of damage to the plant.

${ }^{6} \mathrm{Hours}$ of stability before a $2^{\circ} \mathrm{C}$ rise in temperature of the silage mass after exposure to air.

and plants damaged for $9 \mathrm{~d}$. In contrast, the concentration of starch was lower in plants damaged for $27 \mathrm{~d}$ compared to $9 \mathrm{~d}$ and was also numerically lower than in undamaged plants. The concentration of WSC was lowest in undamaged compared to both damaged plant treatments. Yeasts did not differ among treatments at harvest but corn damaged $27 \mathrm{~d}$ prior to harvest had more molds than undamaged corn. The concentrations of DON, FB1, and ZEA were not affected in plants damaged for $9 \mathrm{~d}$ but were markedly greater in plants damaged for $27 \mathrm{~d}$ when compared to undamaged plants.

The DM recovery and nutrient composition of corn silages after $95 \mathrm{~d}$ of ensiling are shown in Table 5 . There were main effects of PS and D on DM recovery. Corn silage made from silage damaged for $27 \mathrm{~d}$ had the low- est DM recovery of all treatments. Treatment with PS improved DM recovery compared to silages not treated with this additive. Damage to the ears had considerable effects on the nutritive value of ensiled corn silage. Specifically, silage made from plants damaged for $27 \mathrm{~d}$ had the highest concentration of $\mathrm{CP}$ and $\mathrm{NH}_{3}-\mathrm{N}$ of all treatments. The concentration of ADF and WSC in silage increased, whereas the concentration of starch decreased with a longer time of damage to the ear. Treatment with PS had no effects on ADF or starch content of silage but did result in silage with lower CP content than in untreated silage. There was an interaction between PS $\times \mathrm{D}$ for NDF because treatment with PS resulted in a reduction of this component only in silage made from plants damaged for $27 \mathrm{~d}$. The concen-

Table 4. The DM, pH, chemical composition (DM basis), mycotoxins (DM basis), and microbial populations (fresh weight basis) of chopped whole plant corn plants at harvest before treatment with potassium sorbate from experiment 2

\begin{tabular}{lccccc}
\hline Item & Undamaged $^{1}$ & Damaged $9 \mathrm{~d}^{2}$ & Damaged $27 \mathrm{~d}^{3}$ & SEM & $P$-value \\
\hline $\mathrm{DM}, \%$ & $37.6^{\mathrm{a}}$ & $36.2^{\mathrm{ab}}$ & $35.5^{\mathrm{b}}$ & 0.5 & 0.05 \\
$\mathrm{pH}$ & 5.76 & 5.72 & 5.70 & 0.03 & 0.43 \\
$\mathrm{CP}, \%$ & 6.8 & 6.6 & 6.4 & 0.19 & 0.48 \\
$\mathrm{NH}_{3}-\mathrm{N}, \%$ & 0.03 & 0.04 & 0.04 & $<0.01$ & 0.30 \\
$\mathrm{WSC}, \%$ & $3.7^{\mathrm{b}}$ & $5.7^{\mathrm{a}}$ & $6.3^{\mathrm{a}}$ & 0.29 & $<0.01$ \\
$\mathrm{ADF}, \%$ & $25.7^{\mathrm{b}}$ & $25.2^{\mathrm{b}}$ & $29.5^{\mathrm{a}}$ & 0.72 & 0.01 \\
$\mathrm{NDF}, \%$ & 45.4 & 42.4 & 47.3 & 1.45 & 0.13 \\
$\mathrm{Starch}, \%$ & $29.8^{\mathrm{ab}}$ & $31.3^{\mathrm{a}}$ & $25.0^{\mathrm{b}}$ & 1.15 & 0.02 \\
Yeasts, log cfu/g & 5.96 & 5.98 & 6.33 & 0.57 & 0.17 \\
Molds, log cfu/g & $5.51^{\mathrm{b}}$ & $5.69^{\mathrm{ab}}$ & $6.08^{\mathrm{a}}$ & 0.36 & 0.04 \\
Deoxynivalenol, $\mathrm{mg} / \mathrm{kg}$ & $0.90^{\mathrm{b}}$ & $1.67^{\mathrm{b}}$ & $20.65^{\mathrm{a}}$ & 1.64 & $<0.01$ \\
Fumonisin $\mathrm{B}_{1}, \mathrm{mg} / \mathrm{kg}$ & $1.80^{\mathrm{b}}$ & $1.00^{\mathrm{b}}$ & $12.50^{\mathrm{a}}$ & 1.12 & $<0.01$ \\
Zearalenone, $\mathrm{mg} / \mathrm{kg}$ & $0.10^{\mathrm{b}}$ & $0.08^{\mathrm{b}}$ & $2.64^{\mathrm{a}}$ & 0.87 & $<0.01$ \\
\hline
\end{tabular}

${ }^{\mathrm{a}, \mathrm{b}}$ Means in rows with unlike superscript letters differ $P<0.05$.

${ }^{1}$ Whole plant corn with undamaged ears.

${ }^{2}$ Whole plant corn with ears damaged $9 \mathrm{~d}$ before harvest.

${ }^{3}$ Whole plant corn with ears damaged $27 \mathrm{~d}$ before harvest.

${ }^{4}$ Water-soluble carbohydrates. 
tration of residual WSC was greater in silages treated with PS regardless of the forage it was made from but there was an interaction between PS $\times \mathrm{D}$ because it was substantially greater in silage made from corn that was damaged for $27 \mathrm{~d}$. Damaging plants before harvest did not affect the numbers of yeasts and molds in the resulting silage, but addition of PS markedly decreased their numbers. The concentrations of mycotoxins in corn silage generally reflected their concentrations at harvest. Thus, silages made from damaging plants $27 \mathrm{~d}$ before harvest had the highest (numerically or statistically, or both) concentrations of DON, FB1, and ZEA of all treatments. There was no effect of PS on these concentrations of mycotoxins in silage, with the exception that concentrations of DON were higher in silage treated with this compound that had been damaged $27 \mathrm{~d}$ prior to harvest compared to the similar silage without the additive.

The fermentation end products of silages are shown in Table 6. There was an interaction between PS $\times \mathrm{D}$ for silage $\mathrm{pH}$. Treatment with PS resulted in silages with lower $\mathrm{pH}$ for undamaged plants and plants damaged late but had no effect on plants damaged for $27 \mathrm{~d}$. Silage made from plants damaged for $27 \mathrm{~d}$ had greater concentrations of lactic (average of $5.80 \%$ vs. average of $5.19 \%$ for undamaged silage and $4.86 \%$ for silage damaged for $9 \mathrm{~d}$ prior to harvest) and acetic acid (average of $1.29 \%$ vs. average of $1.09 \%$ for undamaged silage and $1.02 \%$ for silage damaged for $9 \mathrm{~d}$ ). Treatment with PS had no effect on the concentrations of lactic acid in silages but compared to silages without the additive, treatment with PS resulted in silages with lower concentrations of acetic acid. The overall trend was for a decrease in the concentration of ethanol in silages treated with PS but there was a PS $\times$ D interaction for ethanol because the decrease was substantially greater in treated corn silage that had been damaged for $27 \mathrm{~d}$. This silage also had greater concentrations of ethanol (average of $2.53 \%$ ) when compared to silages made from undamaged plants (1.39\%) and plants damaged for $9 \mathrm{~d}$ $(1.20 \%)$. No detectable levels of 1,2-propanediol were found in any silages in experiment 2. Aerobic stability was greater in silages treated with PS (average of 157 h) compared with untreated silages (average of $35 \mathrm{~h}$ ) but damage to the plant before ensiling had no effect on this measurement.

\section{DISCUSSION}

When plants are stressed in the field, molds can grow and have the potential to make mycotoxins (Doerr, 2010). Sutton et al. (1980) reported that Fusarium graminearum could enter the corn ear if it had been physically damaged by insects or birds. This damage

Table 5. The DM and chemical composition (DM basis) of corn silage after $95 \mathrm{~d}$ of ensiling in experiment 2

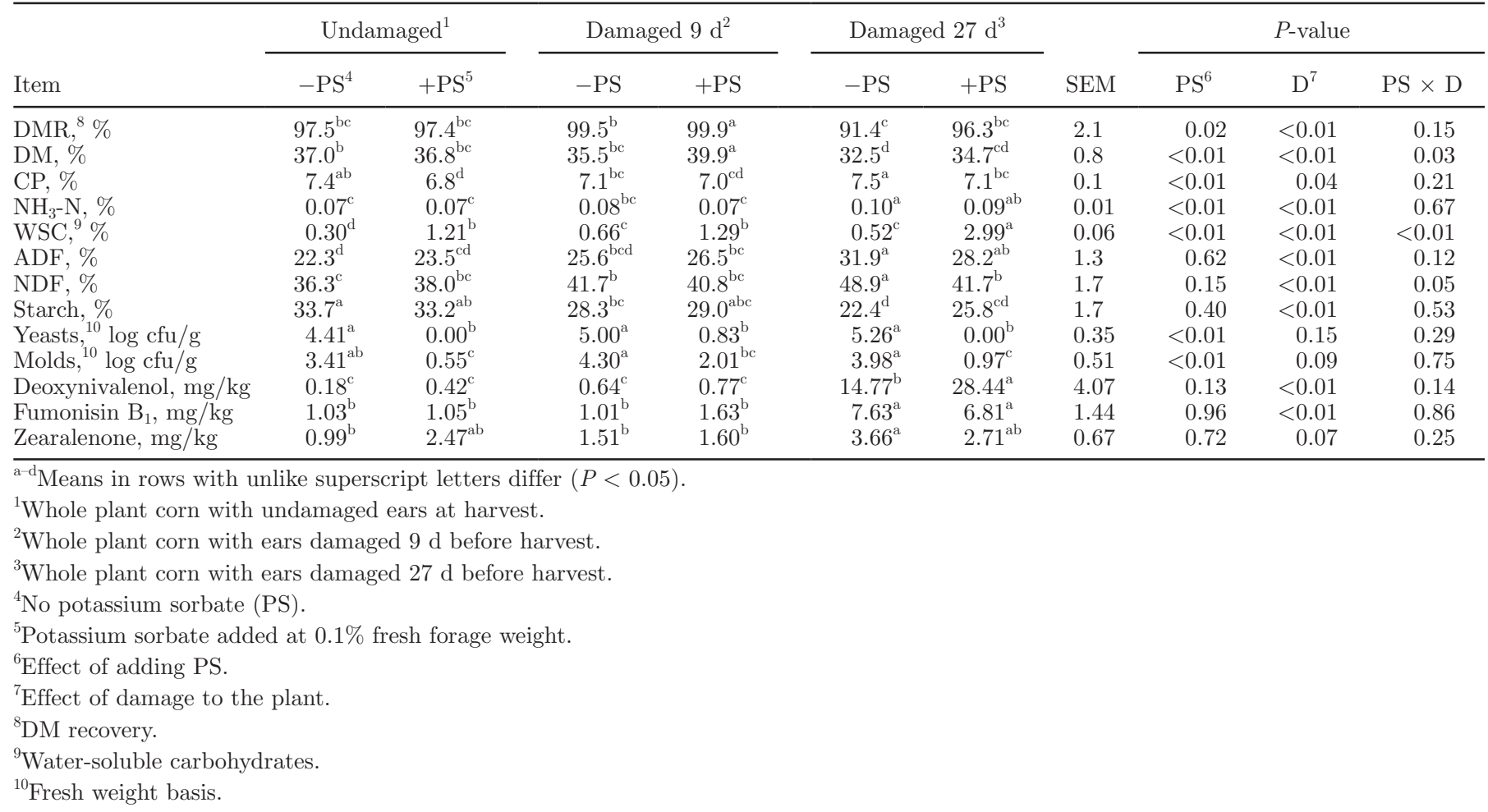


Table 6. The $\mathrm{pH}$, fermentation end products (DM basis), and aerobic stability of corn silage after $95 \mathrm{~d}$ of ensiling in experiment 2

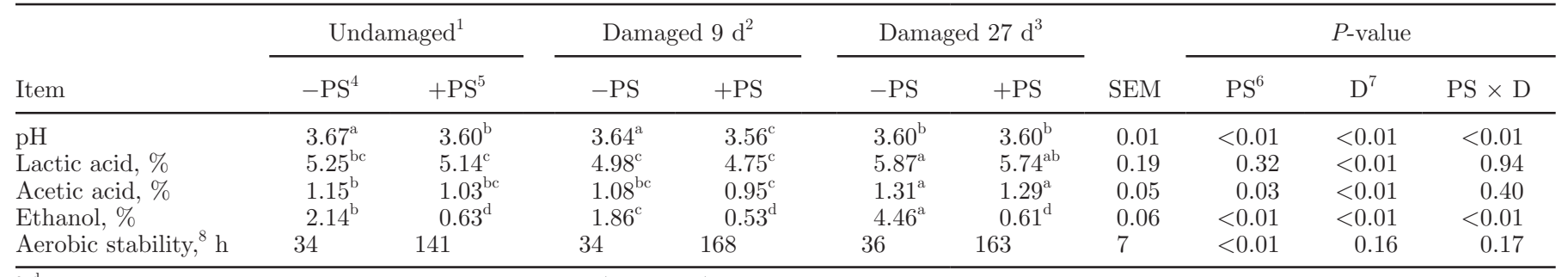

${ }^{\mathrm{a}-\mathrm{d}}$ Means in rows with unlike superscript letters differ $(P<0.05)$.

${ }^{1}$ Whole plant corn with undamaged ears.

${ }^{2}$ Whole plant corn with ears damaged $9 \mathrm{~d}$ before harvest.

${ }^{3}$ Whole plant corn with ears damaged $27 \mathrm{~d}$ before harvest.

${ }^{4}$ No potassium sorbate (PS).

${ }^{5}$ Potassium sorbate added at $0.1 \%$ fresh forage weight.

${ }^{6}$ Effect of adding PS.

${ }^{7}$ Effect of damage to the plant.

${ }^{8} \mathrm{Hours}$ of stability before a $2^{\circ} \mathrm{C}$ rise in temperature of the silage mass after exposure to air.

would expose the endosperm, increasing available moisture and nutrients for fungal growth. Ono et al. (2006) reported markedly greater numbers of Fusarium spp. and greater concentrations of FB1 toxins in naturally damaged versus undamaged corn kernels. However, in our experiments, the numbers of enumerable fungi on plants at harvest were not affected by damage to the ears. In contrast, 1 of 3 mycotoxins increased in experiment 1 and all 3 mycotoxins increased in experiment 2 due to physical damage to the ear, but in the later experiment, the increase was only found in plants that had been damaged for $27 \mathrm{~d}$ before harvest and not in those that had been damaged for $9 \mathrm{~d}$. In the past, mycotoxins have been artificially added to feeds (Rotter et al., 1990; Boudra and Morgavi, 2008) or organisms with potential to produce mycotoxins have been added to silages (Müller and Amend, 1997) to create models for research studies. Collectively, our findings suggest that physically damaging ears of corn prior to harvest might be a method to experimentally produce mycotoxins because feeds with high levels of naturally occurring mycotoxins are not always readily available for study. Our findings also reemphasize the fact that numbers of fungi found on the plant are not always correlated with concentrations of mycotoxins. Undamaged corn plants in our study had levels of mycotoxins that were similar to those reported in previous studies (Mansfield et al., 2005; Schaafsma and Hooker, 2007).

The changes in concentrations of mycotoxins during ensiling have not been consistent when comparing past studies. For example, Fink-Gremmels (2005) suggested that mycotoxins originating during pre-harvest and present before ensiling often remain stable and present in the preserved material for a long period of time. However, Mansfield et al. (2005) reported about a
$50 \%$ reduction in the concentration of DON in fresh versus ensiled samples collected in the Northeastern United States. In addition, Boudra and Morgavi (2008) reported as much as $100 \%$ disappearance of DON in low DM (28\%) corn silage. In our experiments, the concentrations of FB1 increased substantially in silage from levels in fresh forage in experiment 1, remained fairly constant in untreated silage and silage made from plants damaged for $9 \mathrm{~d}$ in experiment 2 , but decreased in concentrations in silage from plants that had been damaged for $27 \mathrm{~d}$. Apparent increases in mycotoxins suggested that there may have been some production during the aerobic phase of ensiling or during storage. Fusarium species mainly produce mycotoxins preharvest but can continue to produce mycotoxins to a smaller extent on the surface of the silo or in oxygen pockets post-harvest (Pelhate, 1977; Lepom et. al., 1990). The reasons for inconsistent findings in our studies and others are unknown at this time.

In experiment 1, L. buchneri was added to silage because it appeared to have potential to reduce mycotoxins in corn silages. For example, Queiroz et al. (2009) reported that adding $L$. buchneri to corn plants infected with rust resulted in silage with less aflatoxin. Iglesias et al. (2005) also reported that L. buchneri tended to lower concentrations of aflatoxin in corn silage but it had no effects on the concentrations of DON or ZEA. In the current study, addition of L. buchneri decreased the concentration only of ZEA in the final silage made from undamaged corn plants. (Aflatoxin levels were not reported in our study but their values were less than 5 to $7 \mu \mathrm{g} / \mathrm{kg}$ and were not affected by any treatment in our experiments.) Potassium sorbate was added in experiment 2 based on the findings of increased mycotoxins during ensiling in experiment 1 . However, treat- 
ment with PS had no effect on the final concentrations of mycotoxins in silages made from undamaged plants or plants damaged $9 \mathrm{~d}$ prior to harvest. Unexpectedly, silage made from plants damaged for $27 \mathrm{~d}$ prior to harvest and treated with PS had more DON than its untreated counterpart. However, the concentration of DON was lower in the silage without PS $(14.77 \mathrm{mg} / \mathrm{kg})$ and higher in the silage with PS $(28.44 \mathrm{mg} / \mathrm{kg})$ when compared to the concentration in freshly harvested plants (20.65), magnifying the difference between these 2 treatments. Overall, the effects of the additives on mycotoxins in our experiments appeared to be variable.

Of the primary nutrients in corn silage, the concentration of starch was consistently lower in plants that had been damaged prior to harvest in both experiments. These findings were probably a result of less-thanoptimal formation and possible degradation of starch as a result of physical damage to some of the kernels in the ear. The fermentation characteristics of corn silages made in our experiments were within the normal range found in previous studies (Kung et. al., 2000; Ranjit et. al., 2002). Damage to the plant prior to harvest appeared to result in silage with more ethanol, possibly because of higher concentrations of WSC and numerically greater numbers of yeasts. However, addition of PS negated this effect, most likely because it markedly lowered the amount of yeasts surviving the ensiling period. In contrast, concentrations of ethanol were not decreased in the final silages treated with $L$. buchneri, even though, like PS, it markedly decreased the numbers of yeasts in silage. This finding may be the result of 2 reasons. First, ethanol is produced by L. buchneri during the anaerobic conversion of lactic to acetic acid (Oude Elferink et al. 2001). Secondly, whereas the antifungal effect of PS is most likely immediate, increased amounts of acetic acid from L. buchneri usually do not occur until after 50 to $75 \mathrm{~d}$ of ensiling (Kleinschmit and Kung, 2006). Thus, yeasts could remain fairly active in the silo and produce ethanol early during ensiling in silages treated with $L$. buchneri. As expected, addition of L. buchneri resulted in silages with more acetic acid and 1,2-propanediol, which are hallmarks of silages treated with this organism.

Physical damage to the ear prior to harvest did not affect the aerobic stability of the resulting silages. Treatment with PS markedly improved aerobic stability, as did INOC with L. buchneri. These effects are similar to those observed for PS in corn silage (Kleinschmit et al., 2005), orange peel silage (Weinberg et al. 1988), and Italian rye grass silage (Shao et al., 2007), and for L. buchneri in a variety of silages (Filya, 2003; Kleinschmit et al., 2005; Adesogan, 2006).

\section{CONCLUSIONS}

Manually damaging ears of corn in the field prior to harvest resulted in increased concentrations of mycotoxins, but the effect differed by study and time of damage prior to harvest. Producers should closely monitor corn silage for concentrations of mycotoxins before feeding, especially if there have been signs of physical plant damage (e.g., hail, bird, or insect damage) prior to harvest. Physically damaging ears of corn prior to harvest might also be a method to experimentally produce mycotoxins in corn plants in the field, but further studies are required to verify the repeatability of our results for this purpose. Applying an additive containing L. buchneri 40788 decreased the concentrations of ZEA in silage made from undamaged corn plants but had no effects on other mycotoxins. Overall, PS had no effect on the concentrations of mycotoxins in the final silage except that concentrations of DON were higher in silage treated with this compound that had been damaged $27 \mathrm{~d}$ prior to harvest compared to similar silage without the additive. Use of PS and L. buchneri 40788 were extremely effective in improving the aerobic stability of corn silage.

\section{ACKNOWLEDGEMENTS}

We thank the staff of the University of Delaware Farm (Newark) for growing and harvesting of the corn silage.

\section{REFERENCES}

Adesogan, A. T. 2006. Mycotoxins in ensiled forages. Pages 44-51 in Key Silage Management Topics. R. Charley, ed. Lallemand Animal Nutrition North America, Milwaukee, WI.

Bennett, G. A., and J. L. Richard. 1994. Liquid chromatographic method for analysis of the naphthalene dicarboxaldehyde derivative of fumonisins. J. Assoc. Off. Anal. Chem. 77:501-506.

Boudra, H., and D. P. Morgavi. 2008. Reduction in Fusarium toxin levels in corn silage with low dry matter and storage time. J. Agric. Food Chem. 56:4523-4528.

CAST (Council for Agricultural Science and Technology). 2003. Mycotoxins: Risks in plant animal and human systems. Task Force Report No. 139. Council for Agricultural Science and Technology. Ames, IA.

Doerr, J. A. 2010. A little fresh air: Fungal toxins and silage. Pages 117-124 in Proc. California Alfalfa and Forage Symposium and Corn/Cereal Silage Mini-Symposium, Visalia, CA. University of California, Davis, CA

Dowd, P. F. 1998. Involvement of arthropods in the establishment of mycotoxigenic fungi under field conditions. Pages 307-350 in Mycotoxins in Agriculture and Food Safety. K. K. Sinha and D. Bhatnagar, ed. Marcel Dekker Inc., New York, NY.

Driehuis, F., M. C. Spanjer, J. M. Scholten, and M. C. te Giffel. 2008. Occurrence of mycotoxins in feedstuffs of dairy cows and estimation of total dietary intakes. J. Dairy Sci. 91:4261-4271.

Filya, I. 2003. The effect of Lactobacillus buchneri and Lactobacillus plantarum on the fermentation, aerobic stability, and ruminal de- 
gradability of low dry matter corn and sorghum silages. J. Dairy Sci. 86:3575-3581.

Fink-Gremmels, J. 2005. Mycotoxins in forages. Pages 249-268 in The Mycotoxin Blue Book. D. E. Diaz, ed. Nottingham University Press, Nottingham, UK.

Hall, M. B. 2000. Neutral detergent soluble carbohydrates nutritional relevance and analysis: A laboratory manual. Univ. of Florida Extension Service, Gainesville, FL.

Iglesias, C., A. Bach, M. Devant, C. Adelantado, and M. A. Calvo. 2005. The effect of Lactobacillus buchneri inoculation on corn silages conservation. Pages 611-613 in Proc. XI Jornadas sobre Producción Animal. Gobierno de Aragón, Servicio de Investigación Agroalimentaria, Zaragoza, Spain.

Jouany, J. P. 2007. Methods for preventing, decontaminating and minimizing the toxicity of mycotoxins in feeds. Anim. Feed Sci. Technol. 137:342-362.

Kleinschmit, D. H., and L. Kung Jr. 2006. The effects of Lactobacillus buchneri 40788 and Pediococcus pentosaceus R1094 on the fermentation of corn silage. J. Dairy Sci. 89:3999-4004.

Kleinschmit, D. H., R. J. Schmidt, and L. Kung Jr. 2005. The effects of various antifungal additives on the fermentation and aerobic stability of corn silage. J. Dairy Sci. 88:2130-2139.

Kung, L. Jr., J. R. Robinson, N. K. Ranjit, J. H. Chen, C. M. Golt, and J. D. Pesek. 2000. Microbial populations, fermentation end products, and aerobic stability of corn silage treated with ammonia or a propionic acid-based preservative. J. Dairy Sci. 83:1479-1486.

Lepom, P., O. Knabe, and H. Baath. 1990. Occurrence of Fusarium species and their mycotoxins in maize. 7. Formation of deoxynivalenol (DON) in a maize plot artificially inoculated with Fusarium culmorum and the influence of ensilaging on the stability of DON formed. Arch. Anim. Nutr. 40:1005-1012.

Mansfield, M. A., E. D. De Wolf, and G. A. Kuldau. 2005. Relationships between weather conditions, agronomic practices, and fermentation characteristics with deoxynivalenol content in fresh and ensiled maize. Plant Dis. 89:1151-1157.

Muck, R. E., and J. T. Dickerson. 1988. Storage temperature effects on proteolysis in alfalfa silage. Trans. ASAE 31:1005-1009.

Müller, H.-M., and R. Amend. 1997. Formation and disappearance of mycophenolic acid, patulin, penicillic acid and PR toxin in maize silage inoculated with Penicillium roquefortii. Arch. Anim. Nutr. 50:213-225.

Munkvold, G. P. 2003. Cultural and genetic approaches to managing mycotoxins in maize. Annu. Rev. Phytopathol. 41:99-116.

Nelson, N. 1944. A photometric adaptation of the Somogyi method for the determination of glucose. J. Biol. Chem. 153:375-380.

Ono, E. Y. S., L. Biazon, M. da Silva, É. Vizoni, Y. Sugiura, Y. Ueno, and E. Y. Hirooka. 2006. Fumonisins in corn: Correlation with Fusarium sp. count, damaged kernels, protein and lipid content. Braz. Arch. Biol. Technol. 49:63-71.

Oude Elferink, S. J. W. H., J. Krooneman, J. C. Gottschal, S. F. Spoelstra, F. Faber, and F. Driehuis. 2001. Anaerobic conversion of lactic acid to acetic acid and 1,2-propanediol by Lactobacillus buchneri. Appl. Environ. Microbiol. 67:125-132.
Pelhate, J. 1977. Maize silage: Incidence of moulds during conservation. Folia Vet. Lat. 7:1-16.

Queiroz, O. C. M., A. T. Adesogan, and S. C. Kim. 2009. Effect of rust infestation on silage quality. Pages 303-304 in Proc. XVth International Silage Conference. G. A. Broderick, A. T. Adesogan, L. W. Bocher, K. K. Bolsen, F. E. Contreras-Govea, J. H. Harrison, R. E. Muck, ed. Univ. Wisconsin, Madison.

Ranjit, N. K., C. C. Taylor, and L. Kung Jr. 2002. Effect of Lactobacillus buchneri 40788 on the fermentation, aerobic stability, and nutritive value of maize silage. Grass Forage Sci. 57:1-9.

Robertson, J. B., and P. J. Van Soest. 1981. The detergent system of analysis and its application to human foods. Page 123 in The Analysis of Dietary Fiber in Food. W. P. T. James and O. Theander, ed. Marcel Dekker Inc., New York, NY.

Romer Labs Inc. 2000. Zearalenone HPLC MycoSep 226. Method 30. Romer Labs Inc., Union, MO.

Rotter, R. G., R. R. Marquardt, A. A. Frohlich, and D. Abramson. 1990. Ensiling as a means of reducing ochratoxin A concentrations in contaminated barley. J. Sci. Food Agric. 50:155-166.

Sampietro, D. A., M. A. Vattuone, D. A. Presello, C. M. Fauguel, and C. A. N. Catalán., and. 2009. The pericarp and its surface wax layer in maize kernels as resistance factors to fumonisin accumulation by Fusarium verticillioides. Crop Prot. 28:196-200.

SAS Institute. 2004. SAS System Software. Release 9.1 (TS1M3). SAS Institute Inc., Cary, NC.

Schaafsma, A. W., and D. C. Hooker. 2007. Climatic models to predict occurrence of Fusarium toxins in wheat and maize. Int. J. Food Microbiol. 119:116-125.

Shao, T., L. Zhang, M. Shimojo, and Y. Masuda. 2007. Fermentation quality of Italian ryegrass (Lolium multiflorum Lam.) silages treated with encapsulated-glucose, glucose, sorbic acid and prefermented juices. Asian-australas. J. Anim. Sci. 20:1699-1704.

Snedecor, G. W., and W. G. Cochran. 1980. Statistical Methods. 6th ed. Iowa State Univ. Press, Ames.

Sutton, J. C., W. Baliko, and H. S. Funnell. 1980. Relation of weather variables to incidence of zearalenone in southern Ontario. Can. J. Plant Sci. 60:149-155

Tacke, B. K., and H. H. Casper. 1996. Determination of deoxynivalenol in wheat, barley, and malt by column cleanup and gas chromatography with electron capture detection. J. AOAC Intl. 79:472-475.

Van Soest, P. J., J. B. Robertson, and B. A. Lewis. 1991. Methods for dietary fiber, neutral detergent fiber, and nonstarch polysaccharides in relation to animal nutrition. J. Dairy Sci. 74:3583-3597.

Weatherburn, M. W. 1967. Phenol-hypochlorite reaction for determination of ammonia. Anal. Chem. 39:971-974.

Weinberg, Z. G., G. G. Pahlow, B. Dinter, and G. Ashbell. 1988. The effect of treatment with urea, sorbic acid, or dehydration on orange peel silage. Anim. Feed Sci. Technol. 20:335-342.

Whitlow, L. W., and W. M. Hagler Jr. 2008. Mold and mycotoxin issues in dairy cattle: Effects, prevention and treatment. Pages 195-209 in Advances in Dairy Technology, Vol. 20: Proc. Western Canadian Dairy Seminar, Red Deer, AB, Canada. University of Alberta, Edmonton, AB Canada. 